\title{
MAMMALS
}

\section{CLOSE ENCOUNTER WITH A STAR-NOSED MOLE}

PETER TAYLOR, P.O. Box 597, Pinawa, MB R0E 1L0, and ROBERT W. NERO, 546 Coventry Road, Winnipeg, MB R3R 1B6

This note describes a nocturnal, winter sighting of a Star-nosed Mole, one of Manitoba's least familiar mammals. The encounter is discussed briefly with respect to the species' known distribution and behaviour. Table 1 gives the coordinates for all Manitoba localities mentioned in this note. Table 2 lists additional localities cited in a 1969 Blue Jay paper by W.H. Beck and A.E. (Ted) Wilson on this species in the province. $^{2}$

Exceptionally mild air bathed southern Manitoba on 7 January 2003, with an unheard-of daytime high of $9^{\circ} \mathrm{C}$ at Pinawa, $120 \mathrm{~km}$ ENE of Winnipeg and a staggering $17^{\circ} \mathrm{C}$ farther west at McCreary. At 10 p.m., a clear sky, no wind, and the temperature still barely below freezing, tempted me (PT) out for a late-evening walk around town.

While following a dimly lit street (Cameron Road) in a wooded area on the northern fringe of town, I saw a small mammal running at the edge of the road. At first sight it resembled a half-grown Norway Rat. Getting closer, I could see a long, tapered snout that suggested a shrew with what appeared to be very prominent whiskers. However, the sturdy tail, roughly $40 \%$ of the animal's total length of about $20 \mathrm{~cm}$, was much too long for a Short-tailed Shrew, the only terrestrial shrew of comparable size in Manitoba.

The animal continued on for about 150 $\mathrm{m}$, evidently forced by a low snowbank to follow the street. It finally turned into a small open area near the Pinawa Hospital, where I briefly cornered it near a pile of snow. In the light of nearby street-lamps, I could see that the "whiskers" were the strange appendages that distinguish the Star-nosed Mole from all other known mammals. These "22 fleshy, finger-like feelers arranged around the tip of the nose" are nicely illustrated by R.W. Sutton in the paper by Beck and Wilson. ${ }^{2}$

When I attempted to pick the animal up, it squeaked vigorously, then quickly escaped and found a crevice under the snowbank. My last contact with it was the prolonged scrabbling sound as it dug beneath the crusty snow. Melting or slumping snow, caused by the unusually warm weather, had probably driven this mole out of its runways to the surface. It is doubtful that it found safety again before starvation or the returning cold temperatures overtook it.

A semi-aquatic mammal, the Star-nosed Mole is often found in and near streams and rivers; the Pinawa sighting was several hundred metres from the nearest running water on the Pinawa Channel and the Winnipeg River. Relatively long legs give this species greater above-ground mobility than other moles. ${ }^{1}$ It is known to be active throughout the year and around the clock, and is more inclined than other moles to forage on the surface. ${ }^{1,5}$ Based on the ease with which it could be overtaken at a brisk walk, the Pinawa mole's speed could be estimated at about $4 \mathrm{~km} / \mathrm{h}$, barely half of one published report of four to five miles an hour (about $7 \mathrm{~km} / \mathrm{h}$ ). ${ }^{5}$ Admittedly, the 
animal may have been impeded by a slippery surface.

Pinawa lies within the known range of the Star-nosed Mole, which occurs in much of northeastern North America and approaches its western distribution limit in eastern Manitoba, reaching as far north as Island Lake. ${ }^{1,2,6,8-11}$ Most reported localities are in the southeastern corner of the province, $60 \%$ of them lying south of the 51 st parallel and east of the 96th meridian (Tables 1 and 2). In a report on the mammals of Riding Mountain National Park in southwestern Manitoba, zoologist J. Dewey Soper accepted a 1932 account of three Star-nosed Moles trapped in the southern part of the park, as well as sightings in "moist, loamy areas" east of Wasagaming. ${ }^{6,9,10}$ Reports of occurrences farther west in eastern Saskatchewan, however, are apparently unconfirmed. ${ }^{2}$

Manitoba sightings are uncommon, and many reports refer to animals either trapped or found dead, with the majority of dated records between December and April. ${ }^{2}$ Several local residents have reported Starnosed Moles found dead, or accidentally trapped, in window wells in or near Pinawa. The exact circumstances were not recorded for a specimen in the University of Manitoba collection, obtained at Pointe du Bois in December 1958. A specimen in the Manitoba Museum was collected at Decimal, east of Brereton Lake, by a snowplow driver on 28 January 1949.

Kevin Campbell, Assistant Professor at the University of Manitoba's Department of Zoology, tells us that several graduate students in that department (Alvin Dyck, Doug Watkinson, Kevin Ellison and John Brubacher) have mentioned seeing Starnosed Moles on top of the snow during winter. Dyck shot a mole, mistaking it for a Norway Rat, on the snow surface near Milner Ridge around 1988. Watkinson captured one while ice fishing near the shore of Big Whiteshell Lake around 1995. Ellison and Brubacher collected a dead mole on the snow surface while cross-country skiing near Mantario Lake in February 2002. During small-mammal studies near the Taiga Biological Study Station at Wallace Lake, Monica Reid-Wong (pers. comm.) snaptrapped a Star-nosed Mole in August 2002, having inadvertently set the trap at the entrance to the mole's burrow in aldertamarack bog habitat.

Twice annually since 1986 , James Duncan has censused small mammals in spruce-tamarack bogs in southeastern Manitoba and adjacent Minnesota. He reports that, as of March 2003, he has never trapped a Star-nosed Mole (pers. comm.). The Great Gray Owls he studies rarely take this species as prey. Jim has found mole remains in just two of the many nests he has monitored: one near Spruce Siding, Manitoba on 2 June 1996 and the second in Minnesota's Roseau Bog on 27 May 1997. Bill Schwartz, who trapped small mammals for many years in a long-running research program at the Whiteshell Laboratories (formerly Whiteshell Nuclear Research Establishment, $10 \mathrm{~km}$ west of Pinawa), recalls capturing Star-nosed Moles just twice.

Capture by trapping might be expected to be rare unless the mole's subterranean runways are specifically targeted. This is borne out by Kevin Campbell's findings (pers. comm.). His research team (see refs 3,4 and 7) has succeeded in live-trapping over 30 Star-nosed Moles near their tunnels in southeastern Manitoba, with the majority captured near Caddy Lake in Whiteshell Provincial Park and near Piney. Farther north, several have been obtained near Cat Lake in Nopiming Provincial Park. The highest concentrations of tunnels were found in sedge meadows, especially those with numerous hummocks containing willows and alder (Piney), and those adjacent to beaver ponds (Caddy Lake) or small streams (Cat Lake). 
TABLE 1 Coordinates of Manitoba mole localities mentioned in the text

\begin{tabular}{|l|c|c|}
\hline Locality & Latitude (N) & Longitude (W) \\
\hline \hline Big Whiteshell Lake & $50^{\circ} 05^{\prime}$ & $95^{\circ} 20^{\prime}$ \\
\hline \hline Brereton Lake & $49^{\circ} 54^{\prime}$ & $95^{\circ} 33^{\prime}$ \\
\hline Caddy Lake & $49^{\circ} 49^{\prime}$ & $95^{\circ} 13^{\prime}$ \\
\hline Cat Lake & $50^{\circ} 36^{\prime}$ & $95^{\circ} 27^{\prime}$ \\
\hline Decimal & $49^{\circ} 53^{\prime}$ & $95^{\circ} 25^{\prime}$ \\
\hline Island Lake & $53^{\circ} 52^{\prime}$ & $94^{\circ} 40^{\prime}$ \\
\hline \hline Mantario Lake & $50^{\circ} 00^{\prime}$ & $95^{\circ} 10^{\prime}$ \\
\hline \hline Milner Ridge & $50^{\circ} 10^{\prime}$ & $96^{\circ} 14^{\prime}$ \\
\hline \hline Pinawa & $50^{\circ} 09^{\prime}$ & $95^{\circ} 53^{\prime}$ \\
\hline Piney & $49^{\circ} 05^{\prime}$ & $95^{\circ} 59^{\prime}$ \\
\hline Pointe du Bois & $50^{\circ} 18^{\prime}$ & $95^{\circ} 33^{\prime}$ \\
\hline Spruce Siding & $49^{\circ} 43^{\prime}$ & $96^{\circ} 03^{\prime}$ \\
\hline Wallace Lake & $51^{\circ} 01^{\prime}$ & $95^{\circ} 21^{\prime}$ \\
\hline \hline Wasagaming & $50^{\circ} 40^{\prime}$ & $99^{\circ} 58^{\prime}$ \\
\hline
\end{tabular}

TABLE 2 Coordinates of additional Star-nosed Mole localities in Manitoba, mentioned by Beck and Wilson ${ }^{2}$

\begin{tabular}{|l|c|c|}
\hline Locality & Latitude (N) & Longitude (W) \\
\hline \hline Black River & $50^{\circ} 49^{\prime}$ & $96^{\circ} 21^{\prime}$ \\
\hline \hline East Braintree & $49^{\circ} 37^{\prime}$ & $95^{\circ} 37^{\prime}$ \\
\hline Elma & $49^{\circ} 52^{\prime}$ & $95^{\circ} 54^{\prime}$ \\
\hline Falcon Lake & $49^{\circ} 42^{\prime}$ & $95^{\circ} 15^{\prime}$ \\
\hline \hline George Lake & $50^{\circ} 15^{\prime}$ & $95^{\circ} 30^{\prime}$ \\
\hline Great Falls & $50^{\circ} 28^{\prime}$ & $96^{\circ} 01^{\prime}$ \\
\hline Manigotagan ** & $51^{\circ} 07^{\prime}$ & $96^{\circ} 18^{\prime}$ \\
\hline \hline Pine Falls & $50^{\circ} 34^{\prime}$ & $96^{\circ} 13^{\prime}$ \\
\hline \hline Rennie & $49^{\circ} 51^{\prime}$ & $95^{\circ} 33^{\prime}$ \\
\hline \hline Whitemouth & $49^{\circ} 57^{\prime}$ & $95^{\circ} 59^{\prime}$ \\
\hline Winnipeg & $49^{\circ} 53^{\prime}$ & $97^{\circ} 09^{\prime}$ \\
\hline
\end{tabular}

** Sometimes spelled Manigotogan. 
In Wisconsin, according to H.H.T. Jackson, "There are many records of [the Star-nosed Mole] being exposed on the snow, and it also frequently makes runways both on the surface and beneath it... It is particularly active in winter as an underwater swimmer under the ice." Jackson noted further that the species is "particularly vulnerable to attack [by predators] when out on the snow in winter." He referred to a specimen killed by boys and a dog on 10 February 1918 "during mild weather that followed six weeks of very severe weather" - rather similar circumstances to the 2003 Pinawa sighting.

I had barely left the mole when a Northern Flying Squirrel glided across the street, landed on a utility pole, scampered to the top, and glided away again into the woods. Including myself, this was a third mammal stirred to conspicuous activity by the exceptionally mild weather! Though flying squirrels are common in Pinawa, I rarely encounter them except for their occasional nocturnal visits to bird feeders.

For readers seeking more information on this fascinating mammal, a wealth of information is available on the Internet. Two Canadian sites that include some delightful photographs are:

http://home.cc.umanitoba.ca/ rmacarth/ starnosephotos.html and http:// www.aquatic.uoguelph.ca/mammals/ freshwater/accounts/mole.htm

1. BANFIELD, A.W.F. 1974. The Mammals of Canada. National Museum of Natural Sciences, Ottawa, and
University of Toronto Press, Toronto, Ontario, pp. 3538 .

2. BECK, W.H. and A.E. WILSON. 1969. The Starnosed Mole in Manitoba. Blue Jay 27:93-95.

3. CAMPBELL, K.L., I.W. MCINTYRE and R.A. MACARTHUR. 1999. Fasting metabolism and thermoregulatory competence of the Star-nosed Mole, Condylura cristata (Talpidae: Condylurinae). Comparative Biochemistry and Physiology Part A 123:293-298.

4. CAMPBELL, K.L., I.W. MCINTYRE and R.A. MACARTHUR. 2000. Postprandial heat increment does not substitute for active thermogenesis in coldchallenged Star-nosed Moles (Condylura cristata). Journal of Experimental Biology 203:301-310.

5. JACKSON, H.H.T. 1961. Mammals of Wisconsin. University of Wisconsin Press, Madison, Wisconsin, pp. 68-73.

6. GREEN, H.U. 1932. Mammals of the Riding Mountain National Park, Manitoba. Canadian FieldNaturalist 46:149-152.

7. MCINTYRE, I.W., K.L. CAMPBELL and R.A. MACARTHUR. 2002. Body oxygen stores, aerobic dive limits and diving behaviour of the Star-nosed Mole (Condylura cristata) and comparisons with nonaquatic talpids. Journal of Experimental Biology 205:45-54.

8. REAUME, T. and S. TOEWS. 1998. Field checklist of the mammals of Manitoba. Manitoba Naturalists Society, Winnipeg, Manitoba.

9. SOPER, J.D. 1952. The mammals of Riding Mountain National Park, Manitoba, Canada. Canadian Wildlife Service, Wildlife Management Bulletin Series 1, No. 7, pp. 10-11.

10. SOPER, J.D. 1961. The mammals of Manitoba. Canadian Wildlife Service, Wildlife Management Bulletin Series 1, No. 17, p. 13.

11. WRIGLEY, R.E. 1986. Mammals in North America. Illustrated by D. Harty. Hyperion Press Ltd., Winnipeg, Manitoba. pp. 149 and 152-153.

"When the turkey was introduced from America to Europe (about 1530), the word 'turkey' was used to describe imported objects that were foreign, strange or exotic. It was at that time a vague term that could refer to Tartary as well as to Asia Minor. Parenthetically, the word is Tartar in origin and means 'brave'." 